\title{
GENESIS OF THE CONSTITUTIONAL REGULATION OF FREEDOM OF ASSOCIATIONS IN UKRAINE
}

\section{ГЕНЕЗА КОНСТИТУЦЙНОЇ РЕГЛАМЕНТАЦЇ̈ АСОЦІАЦЙ В УКРАЇНІ}

\author{
Volkova D.E., Candidate of Law, \\ Associate Professor at the Department of Constitutional Law \\ National University "Odessa Academy of Law"
}

The further movement of Ukraine in the direction of European integration puts before scientists the task of intensifying the study of those institutions of constitutional law, which are traditionally regulated by the Basic Law norms. One of such institutes is the institute of human civil rights and freedoms in Ukraine, a prominent place among the norms of which is given to the freedom of associations.

The right to associate in public organizations plays an important role in its composition.

The article is dedicated to the analysis of the standards of previous Basic Laws which were in force on the territory of the Ukrainian state in the twentieth century in the field of the creation of NGOs.

One of the most important rights in the system of human rights and freedoms is the right to associate in NGOs. This right in Ukraine is now constitutional, and was so during the twentieth century. Relevant norms concerning it contained the Statute on the State System, Rights and Freedoms of the Ukrainian People's Republic (Constitution of the Ukrainian People's Republic, adopted on April 29, 1918), Laws on the Provisional State System of Ukraine proclaimed on April 29, 1918, Constitution of the Ukrainian Socialist Soviet Republic of 1919, The Constitution (Basic Law) of the Ukrainian Soviet Socialist Republic of 1929, the Constitution (Basic Law) of the Ukrainian Soviet Socialist Republic of 1937 and the Constitution (Basic Law) of the Ukrainian Soviet Socialist Republic of 1978. The ongoing process of democratization the provisions of the Ukrainian Constitution 1996 determines the topicality of the research. The previous Basic Laws, which were in force on the territory of the modern Ukrainian state, are analyzed. Of particular interest from this point of view is the previous Constitution (Basic Law) of the Ukrainian Soviet Socialist Republic of 1978 in relation to the Constitution of Ukraine of 1996. Prospects for further research in this direction are seen in considering the feasibility of reproducing in the current Constitution the provisions of the of the Ukrainian SSR's Constitution of 1978 granting the right of legislative initiative to some NGOs, and determining the criteria by which an NGO can obtain such a right.

Key words: NGOs, freedom of association, the right to create NGOs, associations, human rights.

Подальший рух України у напрямі європейської інтеграції ставить перед ученими завдання активізувати дослідження тих інститутів конституційного права, які традиційно регламентуються нормами Основного Закону. Одним із таких інститутів є інститут прав і свобод людини й громадянина в Україні, чільне місце серед норм якого посідають норми, які регламентують свободу асоціацій. Важливу роль у її складі відіграє право на об'єднання в громадські організації.

Стаття присвячена аналізу норм попередніх Основних Законів, які були чинними на території сучасної української держави у XX ст. щодо права на об'єднання в громадські організації.

Одним з найважливіших прав у системі прав і свобод особистості є право на об'єднання в громадські організації. Це право в Україні нині $є$ конституційним і було таким протягом XX ст. Відповідні норми щодо нього містили Статут про державний устрій, права і вольності Української Народної Республіки (Конституція УНР, ухвалена 29 квітня 1918 р.), Закони про тимчасовий Державний устрій України, проголошені 29 квітня 1918 р., Конституція Української Соціалістичної Радянської Республіки 1919 р., Конституція (Основний Закон) Української Соціалістичної Радянської Республіки 1929 р., Конституція (Основний Закон) Української Радянської Соціалістичної Республіки 1937 р. та Конституція (Основний Закон) Української Радянської Соціалістичної Республіки 1978 р. Триваючий в Україні процес розроблення нової Конституції зумовлює актуальність звернення до попередніх Основних Законів, які були чинними на території сучасної української держави. Особливий інтерес з цієї точки зору має попередня по відношенню до Конституції України 1996 р. Конституція (Основний Закон) Української Радянської Соціалістичної Республіки 1978 р. Перспективи подальших досліджень у цьому напрямі вбачаються у розгляді доцільності відтворення у чинному Основному Законі норми Конституції УРСР 1978 р. про надання права законодавчої ініціативи деяким громадським організаціям та визначення критеріїв, за якими громадська організація може отримати таке право.

Ключові слова: громадські організації, свобода об'єднання, право на об'єднання в громадські організації, свобода асоціацій, асоціації, права людини.

Formulation of the problem. The further movement of Ukraine in the direction of European integration puts before scientists the task of intensifying the study of those institutions of constitutional law, which are traditionally regulated by the norms of the Basic Law. One of such institutions is the institute of human rights and freedoms in Ukraine, a prominent place among the norms of which is occupied by the rules on freedom of association. The right to associate in NGOs plays an important role in it.

Of particular interest is the historical experience of regulating this right in previous constitutional acts. In our opinion, this will contribute to the observance of traditions in the field of constitutional law, constitutional succession.

The state of the study. During the Soviet era, the study of constitutional norms on NGOs was given considerable attention by Y.N. Kozlov, V.V. Kravchenko, A.I. Lukyanov, A.I. Shchiglik, C.A. Yampolska. In Ukraine, the study of the constitutional regulation of the right of citizens to unite in NGOs as a component of freedom of association was carried out in their works mostly by researchers who dedicated monographs to this right (O.M. Vashchuk in the dissertation "Constitutional and legal status of NGOs in Ukraine", E.E. Dodina in the dissertation "Administrative and legal status of NGOs in Ukraine" etc.). However, this article provides an author's analysis of the relevant constitutional norms.

The purpose of the article. The purpose of the article is to analyze the constitutional regulation of the right of citizens to unite in NGOs in Ukraine during the XX century.

The main material. In the XX century on the territory of most of modern Ukraine at the constitutional level the right to unite in NGOs was discussed in 7 acts.

The first of them is the Statute on the state system, rights and freedoms of the Ukrainian People's Republic (de facto adopted as the Constitution of the UPR). It was adopted on April 29, 1918. The charter did not enter into force, but the very fact of its adoption makes it appropriate to pay attention to its rules.

In Art. 17 the statute provided that "a citizen of the UPR and no one else in its territory may be restricted in the rights of speech, press, conscience, organization, strike, as long as it does not violate the provisions of criminal law" [1].

As we can see, the right to join NGOs was within the "right of organization". In addition, attention is drawn to the fact that it was provided exclusively to citizens of the UPR. We find 
an argument in favor of this in Art. 20, which states: "only citizens of the UPR enjoy the full range of civil and political rights". Also, already at the constitutional level the possibility of restriction of this right was stipulated - its realization was possible "as long as it does not violate the provisions of criminal law".

Under Hetman P. Skoropadsky, the role of the Constitution was played by the Laws on the Provisional State System of Ukraine proclaimed on the day of his overthrow by him and his supporters of the Central Rada, April 29, 1918.

These laws contained only 44 articles, but one of them was dedicated to the NGOs. Section III "Rights and Responsibilities of Ukrainian Cossacks and Citizens" contained only 12 articles, one of which was dedicated to the consolidation of the right to unite in NGOs. This shows the importance of this right for the authors of the Laws. Article 22 provided that "Ukrainian Cossacks and citizens have the right to unite communities and unions for purposes not contrary to the law" [2]. Again, we see the restriction of this right at the constitutional level: "to unite communities and unions for purposes not contrary to the law". There is also a tendency to grant this right only to citizens.

The Laws on the temporary state system of Ukraine were repealed in December 1918 by the Directory of the Ukrainian People's Republic, which replaced the Hetmanate. And in the spring of 1919, Soviet power was established in most of Ukraine (except the modern western regions).

The first Basic Law of the USSR in Soviet times was the Constitution of the Ukrainian Socialist Soviet Republic of 1919. Paragraph "c" of Art. 3 provided that the state "creates for the working masses the opportunity to enjoy the rights (freedom of speech and press, assembly and association), depriving these rights of the ruling classes and common with them in their political position social groups" [3].

As we can see, in this Constitution the right to unite in NGOs was a component of the freedom of association. It was also limited to the level of the Basic Law - but if in the previous constitutional acts of the twentieth century the restriction concerned the types of organizations formed, in this case the entities that were endowed with this right. As we can see, it was owned by those who belonged to the "working masses".

Ten years later, the Constitution of the USSR in 1919 was updated. It was replaced by the Constitution (Basic Law) of the Ukrainian Soviet Socialist Republic of 1929. It also contained lustration provisions restricting the political rights of those who did not belong to the "working masses". St. 5 of the Constitution provided that "the Ukrainian Socialist Soviet Republic provides political rights for the working masses, regardless of gender, religion, race and nationality and completely deprives them of the rights of the exploiting classes", and Art. 11 told that the right to associate in NGOs was considered a political right - a component of freedom of association: "In order to ensure the workers' real freedom of association, the Ukrainian Socialist Soviet Republic, by breaking the economic and political power of the wealthy classes and thus removing all obstacles which have hitherto prevented workers and peasants in bourgeois society from enjoying freedom of organization and action, promotes workers and peasants in their cause, association and organization" [4].

None of this articles provided, who belonged to the "working masses" and who - to the "exploiting classes". But an analysis of other articles of the Constitution of the Ukrainian People's Republic of 1929 allows us to draw a corresponding conclusion. Thus, the provisions of the Basic Law on Electoral Rights (Articles 66-69) proclaimed that "persons who use hired labor for profit" are not elected and cannot be elected; persons living on unearned income; members of the ruling house in Russia; persons who managed the activities of the police, gendarmerie; officers and agents of the former police, a separate corps of gendarmes and security departments; etc.
The abolition of these restrictions on the range of subjects of the studied law took place only after the establishment of Soviet power on the territory of Ukraine, in the Constitution (Basic Law) of the Ukrainian Soviet Socialist Republic of 1937.

Article 125 of this Constitution provided that "in accordance with the interests of workers and in order to develop organizational initiative and political activity of the masses, the citizens of the USSR are guaranteed the right to unite in public organizations: trade unions, cooperatives, youth organizations, sports and defense organizations, cultural, technical and scientific societies, and the most active and conscious citizens of the working class and other strata unite in the Communist Party (Bolsheviks) of Ukraine, which is the leading detachment of workers in their struggle for the strengthening and development of the socialist system and is the core all workers' organizations, both public and state" [5].

It should be noted that the study of the previous Basic Laws shows that in this wording (with this name) the right to unite in NGOs was stated in the Constitution of the USSR in 1937 for the first time. Prior to that, the Basic Laws referred to the "right to organize" (Statute on the state system, rights and freedoms of the Ukrainian People's Republic in 1918), the "right to unite communities and unions" (Laws on the Provisional State System of Ukraine in 1918), freedom unions (Constitution of the USSR in 1919, the Constitution of the USSR in 1929).

Research of the provisions of Art. 125 provide grounds for drawing a number of conclusions:

- in the Basic Law, despite the absence of provisions on restrictions on the rights of those who according to the Constitutions of 1919 and 1929 belonged to the exploiting classes, it was not about "public organizations" (NGOs as now), but about "public organizations of workers"; after all, it is envisaged that the Communist Party of Ukraine is the leading nucleus of "all workers' organizations, both public and state";

- according to this norm (including others in the Constitution) the existence of a one-party system was traced; on the one hand, the Communist Party, as a political party, dissociated itself from public organizations - only it was a "party", and all other associations were called "unions", "organizations", "societies", etc.;

- the main types of public organizations of workers were trade unions, cooperatives, youth organizations, sports and defense organizations, cultural, technical and scientific societies;

- cooperatives belonged to public organizations; in modern Ukraine, the situation has changed because some types of cooperatives (for example, production cooperatives) operate as business associations, with the main purpose of making a profit;

- the investigated right is granted only to citizens of the USSR; however, it is not limited to other means (only on the basis of the presence or absence of citizenship).

In comparison with all the Basic Laws that were in force in modern Ukraine during the XX century, the Constitution of the USSR in 1978 paid the greatest attention to association in NGOs (its text is analyzed with all the changes and additions that were made to it, that is, in the wording that was in force on the date of entry into force of the Constitution of Ukraine in 1996).

The right to unite in NGOs was enshrined in Art. 49. This article consisted of two parts. Part 1 provided that "in accordance with the goals of communist construction, the citizens of the Ukrainian SSR have the right to unite in NGOs that promote the development of political activity and initiative, the satisfaction of their legitimate interests". Part 2 stated that "NGOs are guaranteed the conditions to perform their statutory tasks" [6].

It should be noted that, as in the Basic Law of the USSR of 1937, the right under study was limited at the constitutional level only by its subject composition. There were no other 
restrictions (such as the 1996 Constitution), which in Article 36 provides that "citizens of Ukraine have the right to freedom of association in political parties and NGOs to exercise and protect their rights and freedoms and to satisfy political, economic and economic rights, social, cultural and other interests, except for restrictions established by law in the interests of national security and public order, public health or protection of the rights and freedoms of others" [7].

The main disadvantage of Art. 49 of the Constitution of the USSR of 1978 from the point of view of regulation of the studied law is that the Constitution of 1996 distinguishes freedom of association in NGOs and in political parties, and the Constitution of the USSR of 1978 provides exclusively the right to unite in NGOs.

The main advantage of Art. 49 are that its part 2 provided: NGOs are guaranteed conditions for performance of the statutory tasks. At the present stage, in order to increase the efficiency of their functioning, NGOs lack state support for their activities (and not necessarily material support). For comparison: Art. 22 of the Law of Ukraine of March 22, 2012 "On Public Associations" provides that "the state ensures the observance of the rights of NGOs" [8].

In addition, NGOs were mentioned in several articles of the Constitution of the USSR in 1978. In particular, they were these.

In Art. 7, which stipulated that "trade unions, the All-Union Leninist Communist Youth Union, cooperatives and other NGOs in accordance with their statutory tasks participate in the management of state and public affairs, in resolving political, economic and socio-cultural issues". In our opinion, this helped to increase the interest of citizens in exercising their right to join NGOs. In addition, here the right to unite in NGOs was organically combined with the right to participate in the management of state and public affairs.

In Art. 47, which provided that "every citizen of the Ukrainian SSR has the right to make proposals to state bodies and NGOs to improve their activities, to criticize shortcomings in the work". Very interesting from the point of view of modern law, this makes sense. After all, now Art. 40 of the Constitution of Ukraine stipulates that "everyone has the right to send individual or collective written appeals or personally apply to public authorities, local governments and officials and officials of these bodies, who are obliged to consider the appeal and give a reasoned response within the statutory period". Thus, the list of subjects of this right has been expanded (according to the Constitution of 1978 - citizens, according to the Constitution of 1996 all), but the list of bodies and organizations to which such an appeal can be addressed has been narrowed, and NGOs (local governments were considered as public authorities), according to the Constitution of 1996 - to public authorities, local governments and officials and officials of these bodies). The Law of Ukraine of March 22, 2012 "On Public Associations" does not contain a similar human right and the corresponding duty of NGO. In our opinion, this is not always correct. For example, if a person has been denied membership in an NGO, it is thought that he or she has the right to know the reasons for the refusal and whether it is possible, if the circumstances change, to apply again to the NGO. Currently in Ukraine there is no discrimination on the basis of membership in NGOs, but sometimes such membership can be important and considered necessary by the person himself. For example, one of the requirements for obtaining the qualification level of CAP (Certified Accounting Practitioner) is a good reputation as a member of a professional organization, which is confirmed by the recommendation of the organization. In case of refusal to accept members of the organization, or refusal to provide a recommendation to a member of the organization, the right to apply to the $\mathrm{NGO}$ and its obligation to respond to the application can be an additional guarantee of a certificate confirming a high professional level as a specialist in accounting.

In Art. 101 enshrined that the right of legislative initiative in the Verkhovna Rada of the Ukrainian SSR belongs to the Presidium of the Verkhovna Rada of the Ukrainian SSR, the Council of Ministers of the Ukrainian SSR, standing and other commissions of the Verkhovna Rada of the Ukrainian SSR, deputies of the Verkhovna Rada of the Ukrainian SSR, the Supreme Court of the Ukrainian SSR the Prosecutor of the Ukrainian SSR, as well as to NGOs represented by their republican bodies. The people's legislative initiative, according to many researchers, has low efficiency (see, for example, [9, p. 158]). But if it is an indirect (mediated through the NGO) initiative - Its effectiveness increases many times over, as the NGO in this case acts as a kind of "filter" of individual proposals that are not supported by the public.

The greater number and significant activity of NGOs in the USSR was explained by the fact that at the constitutional level it was guaranteed that the state creates conditions for them to perform their statutory tasks, as well as by the fact that NGOs were widely involved in exercising such constitutional rights in the management of state and public affairs.

Conclusions. One of the most important rights in the system of human rights and freedoms is the right to associate in NGOs. This right in Ukraine is now constitutional, and was so during the twentieth century. Relevant norms concerning it contained the Statute on the State System, Rights and Freedoms of the Ukrainian People's Republic (Constitution of the Ukrainian People's Republic, adopted on April 29, 1918), Laws on the Provisional State System of Ukraine proclaimed on April 29, 1918, Constitution of the Ukrainian Socialist Soviet Republic of 1919, The Constitution (Basic Law) of the Ukrainian Soviet Socialist Republic of 1929, the Constitution (Basic Law) of the Ukrainian Soviet Socialist Republic of 1937 and the Constitution (Basic Law) of the Ukrainian Soviet Socialist Republic of 1978. The ongoing process of democratization the provisions of the Ukrainian Constitution 1996 determines the topicality of the research. The previous Basic Laws, which were in force on the territory of the modern Ukrainian state, are analyzed. Of particular interest from this point of view is the previous Constitution (Basic Law) of the Ukrainian Soviet Socialist Republic of 1978 in relation to the Constitution of Ukraine of 1996. Prospects for further research in this direction are seen in considering the feasibility of reproducing in the current Constitution the provisions of the of the Ukrainian SSR's Constitution of 1978 granting the right of legislative initiative to some NGOs, and determining the criteria by which an NGO can obtain such a right [9-12].

\section{REFERENCES}

1. Статут про державний устрій, права і вольності Української Народної Республіки (Конституція УНР, ухвалена 29 квітня 1918 р.). Конституції і конституційні акти України. Історія і сучасність. Київ : Юридична думка, 2011. С. 41-49.

2. Закони про тимчасовий Державний устрій України, проголошені 29 квітня 1918 р. Конституції і конституційні акти України. Історія і сучасність. Київ : Юридична думка, 2011. С. 50-53.

3. Конституція Української Соціалістичної Радянської Республіки 1919 р. Конституції і конституційні акти України. Історія і сучасність. Київ : Юридична думка, 2011. С. 56-61.

4. Конституція (Основний Закон) Української Соціалістичної Радянської Республіки 1929 р. Конституції і конституційні акти України. Історія і сучасність. Київ : Юридична думка, 2011. С. 66-80.

5. Конституція (Основний Закон) Української Радянської Соціалістичної Республіки 1937 р. Конституції і конституційні акти України. Історія і сучасність. Київ : Юридична думка, 2011. С. 81-101. 
6. Конституція (Основний Закон) Української Радянської Соціалістичної Республіки 1978 р. із змінами та доповненнями. URL: http://static.rada.gov.ua/site/const/istoriya/1978.html.

7. Конституція України 1996 р. Відомості Верховної Ради України. 1996. № 30. Ст. 142.

8. Про громадські об’єднання : Закон України від 22 березня 2012 р. Офіційний вісник України. 2012. № 30. Ст. 1097.

9. Мішина Н.В. Громадянське суспільство у полісекторних моделях суспільства. Наукові праці Національного університету «Одеська юридична академія». 2018. T. XXII. С. 85-92.

10. Мішина Н.В. Органи самоорганізації населення у системі місцевого самоврядування. Наукові праці Національного університету «Одеська юридична академія». 2019. Т. XXIII. С. 84-91.

11. Волкова Д.Є. Конституційне законодавство про громадські організації: стан та перспективи гармонізації з європейськими стандартами : дис. ... канд. юрид. наук. Одеса, 2015. 217 с.

12.Волкова Д.Є. Міжнародні стандарти про внутрішню структуру громадських організацій. Юридичний вісник. 2012. № 1. С. 71-77. 